\title{
Perception of Dew by Cereal Growers in Semi-Arid Climate (Guéné, North Benin)
}

\author{
Gabin Koto N'Gobi ${ }^{1,4}$, Basile Kounouhéwa ${ }^{1}$, Clément Kouchadé ${ }^{1}$, Romuald Anago ${ }^{2}$, Daniel \\ Beysens ${ }^{3,4 *}$ \\ ${ }^{1}$ Laboratoire de Physique du Rayonnement (LPR), 01BP: 526 FAST, Département de Physique, Université \\ d'Abomey-Calavi (Bénin). \\ ${ }^{2}$ Institut de Recherche Empirique en Economie Politique 02BP: 372 Cotonou (Bénin). \\ ${ }^{3}$ Laboratoire de Physique et Mécanique des Milieux Hétérogènes, CNRS, ESPCI, PSL Research University, \\ Sorbonne Université, Sorbonne Paris Cité, 10 rue Vauquelin, F-75005, Paris, France.
}

${ }^{4}$ OPUR, International Organization for Dew Utilization, 60 rue Emeriau, 75015 Paris, France.

*Corresponding Authors: Daniel Beysens, OPUR, International Organization for Dew Utilization, 60 rue Emeriau, 75015 Paris, France.

\begin{abstract}
West Africa is one of the regions the more impacted by climate change, concerning in particular droughts and lack of fresh water. In this context was carried out a study of the sociological perception of dew as alternate source of water by cereal's growers in Guéné (semi-arid region, north Benin). Ten data collectors were formed to fill out questionnaires, addressed to 100 cultivators in 2014. Data analysis takes into account respondents' gender, their ages and the type of cereal they cultivate. Close to $80 \%$ of the growers experienced dew assistance when sowing cereals. During rain shortage, $44 \%$ of the farmers rely on dew occurrence to compensate for lack of rain water. Among farmers, $80 \%$ account for dew before and during cereals growth. For 99\% of growers, dew plays an important role for cereal growth, as stated in scientific literature. However, $17 \%$ point out a possible negative role of dew, favoring dissemination of plant diseases. Farmers (87\%) are open to any technology capable of collecting enough dew water for agriculture, but they remain skeptical about such discoveries. Responses only slightly vary when considering the gender and the ages of the farmers but they vary strongly when considering the type of cereal.
\end{abstract}

Keywords: Dew, Survey, Cereal Growers, Semi-Arid Area, Guéné, Northern Benin

\section{INTRODUCTION}

Nowadays, extreme climate variability leads to severe human consequences, notably concerning droughts in arid and semi-arid regions where water availability is already low under normal conditions [1]. West Africa is recognized to be one of the regions in the world the most vulnerable to extreme climate variability [1]. Population is indeed mostly rural with agriculture as the main source of income. This is especially true in the extreme northern part of Benin, where water is often scarce. In these regions, growers are said to produce several varieties of cereals every year (maize, sorghum and millet) thanks to a traditional knowledge in dew water management, even though the yields are low. Unfortunately, these traditional methods of agricultural and water management are often lacking of scientific knowledge and never cited.

Dew is an ubiquitous phenomenon in which water vapor condenses on various types of natural or artificial surfaces, such as grass, crops, roofs or vehicles. Dew occurs at night when humid air condenses on surfaces as its temperature falls below the dew point temperature of the surrounding atmosphere. Substrate cooling is ensured by the nocturnal radiative deficit with atmosphere. Low wind speed and clear skies are favorable to dew events. Dew formation has been the object of scientific researches over many years [2]. There is abundant literature reporting that, even though dew amount is small, it can be beneficial to humans [3]. Dew water can be used as fresh water and can give additional water to plants and desert animals, not only in arid and semi-arid areas, but also in humid regions where drought can suddenly occur for more than weeks or months during the rainy seasons. Dew, however, can cause plants diseases through stagnant dew water on their surfaces. Dew can indeed promote the development of pathogenic gems and increasing disease frequency in crops [4]. 
To our knowledge, no sociological studies have been conducted so far to explore the use of dew water in agriculture. It is thus worth looking more closely at these aspects of human adaptation as far as dew water is concerned. Extreme weather and climate events have major negative impacts on food security and economy income. These realities illustrate the need to understand the sociological knowledge of dew in relation with cereal growth in view of its possible utilization as alternate or adaptive technology for improving agriculture and mitigate climate extreme impacts. As a matter of fact, since the 1990's, experimental studies have been conducted on dew collection throughout Benin, using efficient conical dew condensers $[5,6]$.

The following is thus concerned with the perception of dew by the grower's rural population through a statistical investigation at Guéné, a typical village in a semi-arid region of northern Benin. The objective of this study is to highlight the understanding of cereal's growers in Guéné concerning the significance of dew in their daily agricultural activities. In particular, correlation analyses are performed between (i) the responses and the respondent gender, (ii) the responses and the respondent ages and (iii) the responses and the type of sown cereals.

\section{MATERIALS AND METHODS}

\subsection{Site Description}

The survey was performed in the village of Guené $\left(\sim 1,560 \mathrm{~km}^{2}\right)$, located in West Africa in the northern part of Benin. Guéné is located within about $750 \mathrm{~km}$ from the economical capital city Cotonou, at $11^{\circ} 20^{\prime}-12^{\circ}$ latitude north and $2^{\circ} 5^{\prime}-3^{\circ} 05^{\prime}$ longitude east (Fig. 1). The elevation is about $250 \mathrm{~m}$ a.s.l. Guéné is characterized by a north Sudanian climate with two different seasons per year [7]. The rainy season period often lasts from May to September; it is followed by a long and dry season from October to April. Harmattan is a dry and dusty wind, which blows north-east, from the Sahara desert and frequently reaches Guéné between November and February [7]. Guéné is at about $30 \mathrm{~km}$ from the south Niger River. The climate is semi-arid and the area's precipitations highly vary in both volume and spatial distribution from year to year. Alike certain western African countries, the Guéné area suffers from unpredictable extreme weather conditions, heavy floods and droughts. Mean annual rain amount and temperature are respectively $\sim 750 \mathrm{~mm}$ and $\sim 30.6^{\circ} \mathrm{C}$. December is the coldest month $\left(\sim 20.3^{\circ} \mathrm{C}\right)$ and April is the hottest month $\left(\sim 42.1^{\circ} \mathrm{C}\right)$.

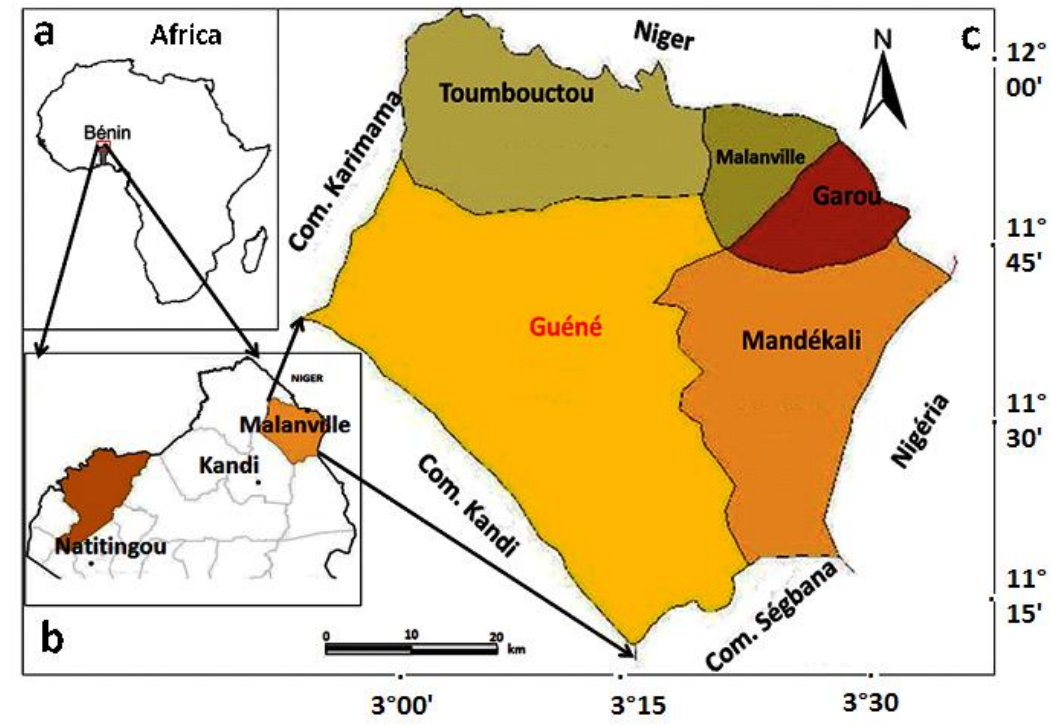

Fig1.(a) Location of Benin in West Africa, (b) Location of the Malanville region in Northern Benin, (c) Location of the Guéné area in the Malanville region

\subsection{Data Collection and Analysis Methods}

Data are collected during an investigation carried out in Guéné from July 19, 2014 to July 26, 2014. For this investigation, 10 data collectors, natives of Guéné, assisted in filling out the questionnaires after talking with the respondents. The main reasons for using natives of Guéné are the following. (i) Facilitate the immersion of the investigators in the population, (ii) ensure confidence between the growers and the interviewers, a necessary condition to maintain credibility of their information and 
(iii) guarantee that the collectors will rapidly master the questionnaires thanks to their good education level.

The interview is based on "face-to-face" conversations, using the language chosen by the farmers (French or Dendi, a local language). The main indicators or information that the questionnaires aim to collect are organized in four main aspects. (1) Demographic information about the growers, particularly their name, gender, age, level of education, the type of cereals sown, their experience as producer of cereals, etc. Their ages were divided in three intervals: [19 - 35[years (G1), [35 - 55[years (G2) and [55 - 70] years (G3), as frequently appeared in the sample. (2) Specific information from the respondents regarding climatic parameters that often influence the production yield. (3) Information concerning dew knowledge (regarding the utility of dew and their experience of dew water contribution in agriculture). (4) Information on grower attitudes concerning the adoption of new technologies for dew harvesting.

After the collection and quality-control, the respondent's data were transferred to a database in a saving system "Census and Survey Processing System (CSPro 5.0)". A double entry was done in order to correct the eventual data entry mistakes. Then the tabulations and the statistical analyses were performed simultaneously with SPSS for Windows (SPSS Inc., Chicago, Standard version 17.0) and STATA statistical software. Descriptive analysis in terms of frequency and percentage were performed on questionnaires data.

\subsection{Samples Presentation}

The investigated sample is constituted of 100 representative producers of cereals in which 97 growers are mainly from Guéné and 3 other growers from neighboring villages. The sample counts 93 men and 7 women. Unfortunately, only 7 women had accepted to answer the questionnaires. The majority of the interviews were carried out in Dendi language (94\%), since nearly $78 \%$ of the growers had a level of instruction that does not exceed the primary level. Table 1 presents the characteristics of the sample.

Table1. Summary of demographic and farming characteristics

\begin{tabular}{|c|c|c|}
\hline \multicolumn{2}{|c|}{ Variables } & $\begin{array}{c}\text { Mean or } \\
\text { percentage }(\%)\end{array}$ \\
\hline \multirow[t]{2}{*}{ Gender } & Male & 93 \\
\hline & Female & 7 \\
\hline \multirow[t]{4}{*}{ Instruction level } & None & 53 \\
\hline & Primary & 27 \\
\hline & Secondary & 15 \\
\hline & University & 5 \\
\hline \multirow{4}{*}{ Cereals } & Sorghum & 76 \\
\hline & Millet & 58 \\
\hline & Maize & 99 \\
\hline & Fonio & 1 \\
\hline \multirow{4}{*}{ Economy } & Missing & 3 \\
\hline & Subsistence & 24 \\
\hline & Sale & 9 \\
\hline & Sale \& subsistence & 64 \\
\hline \multirow[t]{3}{*}{ Seasons } & Rainy & 100 \\
\hline & Dry & 0 \\
\hline & Rainy and dry & 0 \\
\hline \multirow[t]{3}{*}{ Age } & Mean & 37.31 \\
\hline & Min & 19 \\
\hline & $\operatorname{Max}$ & 70 \\
\hline \multirow{3}{*}{$\begin{array}{l}\text { Year of } \\
\text { experience }\end{array}$} & Mean & 20.61 \\
\hline & Min & 2 \\
\hline & Max & 60 \\
\hline \multirow{3}{*}{$\begin{array}{l}\text { Cultivated } \\
\text { surface (ha) }\end{array}$} & Mean & 7.21 \\
\hline & Min & 1 \\
\hline & Max & 60 \\
\hline
\end{tabular}


The mean age of the growers is $\sim 37$ years, with an average of 20 years in agriculture practice. The mean surface allocated to cereals growth in the sample is 7.2 ha, with a minimum area of 1 ha and a maximum area of 60 ha. The sample represents well the diversity of main cereal tendencies in the region. Among the respondents, maize is cultivated by $99 \%$, Sorghum by $76 \%$ and millet by $58 \%$. Only $1 \%$ of the farmers produce "fonio", a regional cereal. All producers report that they cultivate the cereals in the rainy season. Only $9 \%$ of the growers produce cereals for sale, $24 \%$ cultivate for subsistence while $64 \%$ of the farmers produce cereals for both trade and subsistence. The results are presented, analyzed and discussed in the sections below.

\section{RESULTS}

Results are analyzed regarding the following four main points: (i) knowledge of seasons, rain and wind; (ii) farmers experience of dew process in their environment, its utility and utilization; (iii) attitudes towards adoption of new technologies (dew harvesting) and (iv) analysis of answers in view of respondents' gender, ages and type of cereals they cultivate.

\subsection{Farmers Knowledge of Seasons, Rain and Wind}

Water is an important factor that determines the success of agriculture in general and cereals production in particular. In order to facilitate the dialogue, some of the questions were intentionally very basic.

It is obvious that most of the farmers master the rainy and dry seasons of the study area because they are native of the village and have lived there for long. However, different answers are obtained when it is asked «in which months does each of the seasons usually start or end? » The majority agrees that the rainy season usually begins in May (86\%) and ends in October (74\%). The dry seasons often starts in November (51\%) and ends in April (62\%).

To the question whether rain is often sufficient for cereals growth, farmers answer that rain is not always sufficient (73\%). A majority of the growers (99\%) declares that their cereals are often victim of rain shortages during the rainy season, which can last up to 23 days on average. In this case, to compensate for the lack of water, $44 \%$ declare that they rely on dew occurrence in their fields. Otherwise, for wind regimes, the growers believe that wind is more abundant in the morning (48\%) and during night (46\%).

Farmers have thus a good knowledge of their environment. What they know about dew is discussed below.

\subsection{Dew: Knowledge, Utility and Various Utilizations}

All the growers (100\%) have their own idea of what dew is, because they observe it for a longtime. They try accordingly to give a definition of dew. For instance, most of them think that «dew is water, or drops of rain fallen down from the sky and usually observed in the early morning on objects such as vegetables, canopy, plants leaves, shrubs, etc.». Interestingly, they also notice (81\%) that dew is different from fog.

When one asks in which month dew is mostly observed, different responses are given. According to $45 \%$ of the investigated people, dew is abundant during August, $83 \%$ declare that dew is most abundant in September and 66\% declare that October is the month in which dew is the most abundant in Guéné. In addition, $80 \%$ of the growers declare that dew can be observed in the morning; in contrast $46 \%$ of them declare that dew is usually observed during the night. Growers also say that the substrates on which they often observe dew are: leaves of plants (100\%), roofs of the houses (44\%), soil (25\%) and vehicles (19\%). In addition, the growers highlight factors inhibiting dew formation. For example, they cite a hot soil temperature during night (44\%), cloud cover (34\%) and large wind speed $(31 \%)$. They also indicate that dew formation can vary dependently from the season $(42 \%)$.

From the survey, regarding the utility of dew for cereals growth, respondents' opinion is almost unanimous (99\%) in saying that dew plays an important role for cereals growth. Some declarations were mentioned: «after dew events, cereals plants or vegetables that greatly need little water come back to life», «dew helps plants by wetting them, bringing them water through soil and humidity when rain is lacking or in period of long drought», «dew can help certain plants to grow, even when there is a lack of rain», «dew helps plants in difficult growing times», «it contributes to reinforce 
plant's roots», «dew permits several cereals' leaves to become green», «dew helps the survival and the growth of plants», «dew helps plants to finish their vegetative growth», etc.

Otherwise, when one asks the farmers in which phase dew is most useful, regarding the six main stages of cereals growth, $64 \%$ declare that dew is more useful for cereals during the maturation phase (called physiological maturity phase), 52\% think that dew is more useful during the stage of flowering, 32\% think that dew is more important in the raised up phase, $10 \%$ think that dew is most important for the germination phase. For $2 \%$ of the growers, dew is of benefit for cereals during the stages of harvest (tasseling) and the stage of senescence (1\%).

In contrast to the positive perceived benefits of dew, some growers declare that dew could be harmful for cereals $(17 \%)$. For example, some of them say that dew is especially harmful for the «abandoned harvests», «it is harmful for fruits especially when they fall down» and «dew can also contribute to turn black certain cereals seedlings, such as millet and sorghum». In addition, when one asks them about the particular stage of cereals growth in which dew could be harmful, the growers believe that dew is more harmful in the harvest stage (11\% of the sample or $65 \%$ of those who declared that dew could be harmful to plants). Finally, dew is thought to have also harmful effects on cereals in the stage of maturation (4\%, or about $24 \%$ of those who declared that dew could be harmful to the growth of cereals).

Concerning dew utilization, $80 \%$ of the growers declare that they account for dew before and during the growth of their cereals. Close to $80 \%$ of the growers affirm that, in their own experience, dew has assisted their cereals growth. Most growers illustrate the role of dew by affirming that «dew helps cereals in the periods of drought or during rain shortage», «it brings humidity to the plants», «dew impact is especially great after the last weeding toward the end of the rainy season», «dew improves cereals good maturation», «it comes in support to the cereals, two or three days after a rainy day», «dew contributes to the growth of cereals as sorghum, millet, maize in period of rainy break».

When one asks them what source of water they substitute for rain when lacking or not sufficient, $56 \%$ of growers declare to use water from wells for irrigation, $44 \%$ declare to count on dew. They gather wild grasses around cereals plants, dew condensed from the leaves into the gathered grasses and reach the roots of the plants. They also think that plants absorb dew from atmosphere directly.

\subsection{Attitudes towards Adoption of New Technology for Dew Water}

A number of questions were asked to the growers in view of the promotion of a new technology that could help to collect and store dew water for utilization in agriculture. It was asked «whether they think possible to collect dew water?», «would they agree to adopt a technology that would permit them to collect dew water and in what conditions could they use dew water?». Only $15 \%$ of the respondents believe that it is possible to collect dew water using materials. They proposed many ways to collect it. Among the possibilities of dew harvesting, they answered that «bowls» or «calabashes» can be deposited for recovering dew at night or early morning. They also mentioned «enter in the moistened shrubs and let their cloths absorb dew that may be squeezed from cloths», «utilize cloths to collect dew from roofs or plant's leaves». Moreover, $87 \%$ say that they can adopt new technology that could help them to collect dew, at least if it is feasible and unexpensive. However, they remain doubtful regarding the efficiency of any method for collecting a sufficient amount of dew.

\subsection{Analysis of Responses Regarding Ages, Gender and the Kind of Cultivated Cereals}

Table 2 presents the results of the survey taking into account the way that farmers respond in the three different groups of ages (G1, G2 and G3) and the gender (male or female). Several points are concerned from the table. Maize is the cereal most sown regardless the group of ages (100\% G1, 98\% G2 and 99\% G3) and the gender (98\% male, 100\% female) of the respondents. However, regarding the sufficiency of rain to cereals growth, $75.3 \%$ and $42.9 \%$ of males and females, respectively, agree, no matter what age they are $(80.5 \% \mathrm{G} 1,63.7 \% \mathrm{G}$ and $71.4 \% \mathrm{G} 3)$, that rain is insufficient. So $98.9 \%$ and $100 \%$ respectively of males and females, regardless the ages $(100 \%, 98 \%, 100 \%)$ are aware of rain interruptions during the rainy seasons. Furthermore, in order to compensate the lack of water during those rain interruptions, most of the elders $(71.4 \% \mathrm{G} 3$,) believe that dew is mostly used by cereals to mitigate water scarcity. However, $71.4 \%$ of females of the same group of age have opposite opinion. 
Perception of Dew by Cereal Growers in Semi-Arid Climate (Guéné, North Benin)

Table2. Results of the survey taking into account farmers knowledge of: seasons, dew role in cereals growth, factors affecting dew amounts and farmers attitude of adapting any dew harvesting technology

\begin{tabular}{|c|c|c|c|}
\hline Rain season start month & Number & Percentage & Valid Percentage \\
\hline April & 1 & 1 & 1.0 \\
\hline May & 86 & 86 & 86.0 \\
\hline June & 12 & 12 & 12.0 \\
\hline Rain season end month & Number & Percentage & Valid Percentage \\
\hline June & 1 & 1 & 1.0 \\
\hline September & 20 & 20 & 20.0 \\
\hline October & 74 & 74 & 74.0 \\
\hline November & 4 & 4 & 4.0 \\
\hline Dry season start month & Number & Percentage & Valid Percentage \\
\hline September & 6 & 6 & 6.0 \\
\hline October & 34 & 34 & 34.0 \\
\hline November & 51 & 51 & 51.0 \\
\hline December & 7 & 7 & 7.0 \\
\hline Dry season end month & Number & Percentage & Valid Percentage \\
\hline February & 1 & 1 & 1.0 \\
\hline March & 12 & 12 & 12.0 \\
\hline April & 62 & 62 & 62.0 \\
\hline May & 20 & 20 & 20.0 \\
\hline June & 3 & 3 & 3.0 \\
\hline \multicolumn{4}{|c|}{ Rain sufficiency during rainy seasons } \\
\hline & Number & Percentage & Valid Percentage \\
\hline Yes & 27 & 27 & 27.0 \\
\hline No & 73 & 73 & 73.0 \\
\hline \multicolumn{4}{|c|}{ Cereals are victims of shortage during rain season } \\
\hline & Number & Percentage & Valid Percentage \\
\hline Yes & 99 & 99 & 99.0 \\
\hline No & 1 & 10 & 1.0 \\
\hline \multicolumn{4}{|c|}{ Source of water during shortage in rainy season } \\
\hline & Number & Percentage & Valid Percentage \\
\hline Backwater No & 100 & 100 & 100.0 \\
\hline Yes & 0 & 0 & 0.0 \\
\hline Well Yes & 2 & 2 & 2.0 \\
\hline No & 98 & 98 & 98 \\
\hline Dew Yes & & 44 & 44.0 \\
\hline No & & 56 & 56.0 \\
\hline \multicolumn{4}{|c|}{ Wind occurrence period } \\
\hline None period Yes & 2 & 2 & 2.0 \\
\hline No & 98 & 98 & 98.0 \\
\hline Morning Yes & 48 & 48 & 48.0 \\
\hline No & 52 & 52 & 52.0 \\
\hline Evening Yes & 20 & 20 & 20.0 \\
\hline No & 80 & 80 & 80.0 \\
\hline Night Yes & 46 & 46 & 46.0 \\
\hline No & 54 & 54 & 54.0 \\
\hline Dew is helpful for cereals Yes & 99 & 99 & 99.0 \\
\hline No & 1 & 1 & 1.0 \\
\hline Dew is the same to fog Yes & 14 & 14 & 14.0 \\
\hline No & 81 & 81 & 81.0 \\
\hline \multicolumn{4}{|c|}{ Dew highest amount months } \\
\hline June Yes & 4 & 4 & 4.0 \\
\hline No & 96 & 96 & 96.0 \\
\hline July Yes & 26 & 26 & 26.0 \\
\hline No & 74 & 74 & 74.0 \\
\hline August Yes & 45 & 45 & 45.0 \\
\hline No & 55 & 55 & 55.0 \\
\hline September Yes & 83 & 83 & 83.0 \\
\hline No & 17 & 17 & 17.0 \\
\hline
\end{tabular}


Perception of Dew by Cereal Growers in Semi-Arid Climate (Guéné, North Benin)

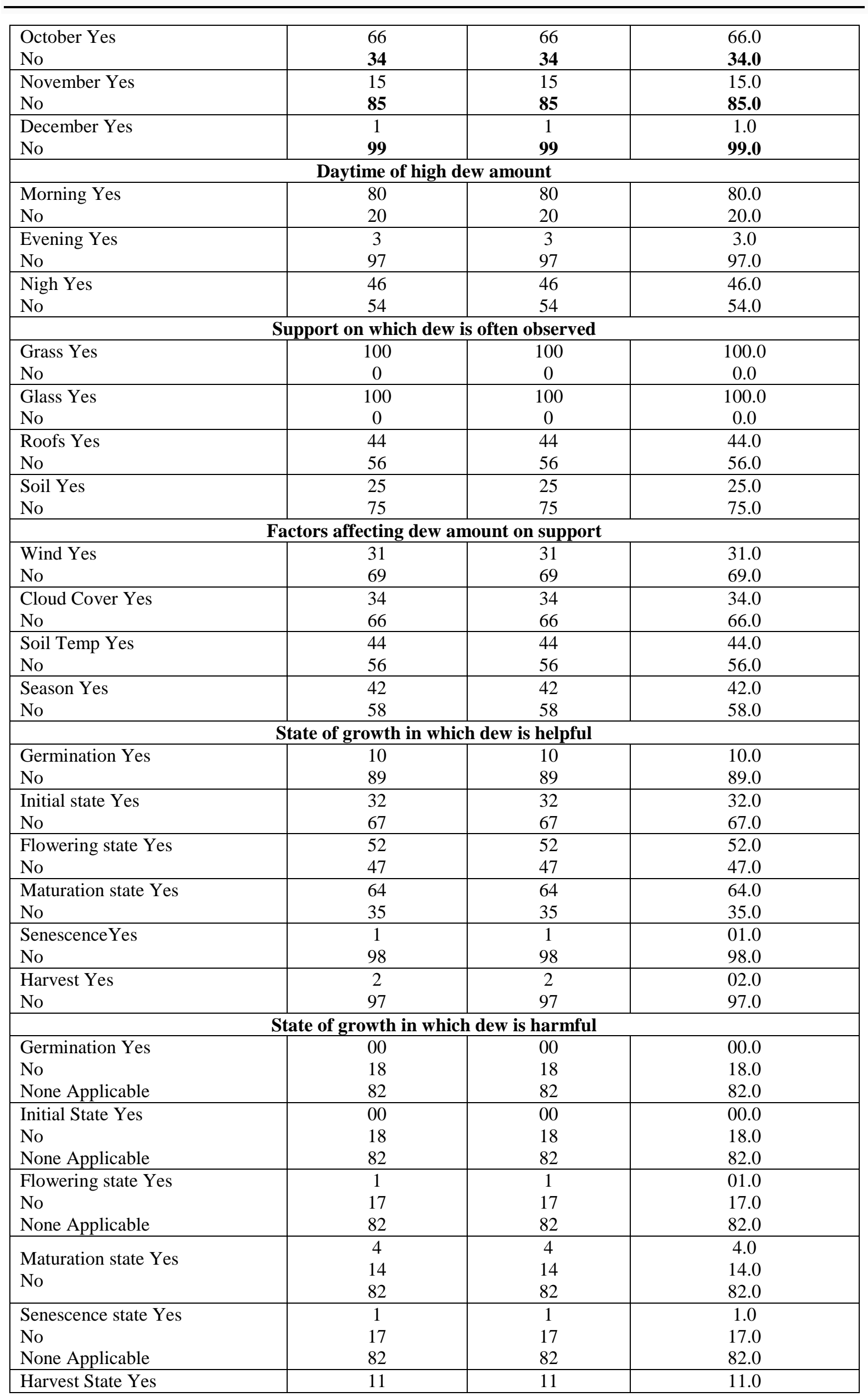




\begin{tabular}{|c|c|c|c|}
\hline $\begin{array}{l}\text { No } \\
\text { None Applicable }\end{array}$ & $\begin{array}{c}7 \\
82\end{array}$ & $\begin{array}{c}7 \\
82\end{array}$ & $\begin{array}{l}07.0 \\
82.0\end{array}$ \\
\hline \multicolumn{4}{|c|}{ Dew is forecasting in cereals growth } \\
\hline Yes & 80 & 80 & 80.0 \\
\hline No & 19 & 19 & 19.0 \\
\hline \multicolumn{4}{|c|}{ Dew is ever experienced } \\
\hline Yes & 80 & 80 & 80.0 \\
\hline No & 19 & 19 & 19.0 \\
\hline \multicolumn{4}{|c|}{ State of growth at which dew is experienced } \\
\hline Germination Yes & 6 & 6 & 06.0 \\
\hline No & 74 & 74 & 74.0 \\
\hline None Applicable & 20 & 20 & 20.0 \\
\hline Initial state Yes & 25 & 25 & 25.0 \\
\hline No & 55 & 55 & 55.0 \\
\hline None Applicable & 20 & 20 & 20.0 \\
\hline Flowering state Yes & 39 & 39 & 39.0 \\
\hline No & 41 & 41 & 41.0 \\
\hline None Applicable & 20 & 20 & 20.0 \\
\hline Maturation state Yes & 50 & 50 & 50.0 \\
\hline No & 30 & 30 & 30.0 \\
\hline None Applicable & 20 & 20 & 20.0 \\
\hline Senescence Yes & 3 & 3 & 03.0 \\
\hline No & 77 & 77 & 77.0 \\
\hline None Applicable & 20 & 20 & 20.0 \\
\hline Harvest State Yes & 1 & 1 & 01.0 \\
\hline No & 79 & 79 & 79.0 \\
\hline None Applicable & 20 & 20 & 20.0 \\
\hline Dew technology Adaption & 87 & 87 & 87.0 \\
\hline Yes & 11 & 11 & 11.0 \\
\hline $\begin{array}{l}\text { No } \\
\text { None Applicable }\end{array}$ & 2 & 2 & 02.0 \\
\hline Total & 100 & 100 & 100.0 \\
\hline
\end{tabular}

Even if a significant proportion of females (100\%) and males (79.6\%) think that dew is different from fog, female (42.9\%) think that dew is not abundant in early mornings against males $(82.8 \%)$ regardless their ages, respectively $80.5 \%$ in $\mathrm{G} 1,83.7 \%$ in G2 and $71.4 \%$ in G3. However, females $(100 \%)$ believe that dew is abundant at night time.

All the respondents $(100 \%)$ believe that dew can form on grasses. Coming to the identification of the main factors affecting dew occurrence: wind, cloud cover, soil temperature and seasons, respectively, $33.3 \%, 34.3 \%, 46.2 \%$ and 38.7, answer that these factors affect dew formation. Both females (100\%) and males $(78.5 \%)$, respectively, estimates that dew occurrence is one of the main source of water during the seeding seasons for cereals, no matter in which group of age they are $(82.9 \% \mathrm{G} 1,75.5 \%$ G2 and $85.7 \mathrm{G} 3$ ). $79.6 \%$ of male and 85.7 of female agree that dew helps cereal's growth.

Concerning the responds regarding the type of cereal the farmers grow, one can find that farmers in Guéné do not sow other cereals out of sorghum, millet, maize or fonio. The statistics show that the majority of the farmers sow maize (99\%) and sorghum (58\%), indicating that there is less influence of the farmers who sow millet $(58 \%)$ and fonio $(1 \%)$ in the responses. The respondents $(80 \%)$ who cultivate maize plan a probable contribution of dew before they sow their cereals and those $(87 \%)$ who sow sorghum agree to adopt any technology of dew collection in their farm. But $49 \%$ of maize and sorghum sowers require an efficient technology. $99 \%$ of the two cereal sowers claim that dew contribution is spontaneous in plant growth especially at the ripening (64\%) and flowering (52\%) stages of growth. However $69 \%$ think that dew can be harmful. The answers from this category of investigation indicate that $100 \%$ of the farmers sowing both maize and sorghum know dew and fog and $76 \%$ of them indicate that the two phenomena are different. On the other hand, $66 \%$ think that dew can be used for irrigation.

Even if the percentage can somewhat vary from a group of age or the gender to another, all the answers to the main questions concord when the analyses are performed taking into account the ages and the gender of the respondents. However, the correlation of the responses from the farmers who sow sorghum and millet indicate that the answers depend on these sowers. 
Perception of Dew by Cereal Growers in Semi-Arid Climate (Guéné, North Benin)

Table3. Results of the survey taking into account the gender and the ages of the respondents

\begin{tabular}{|c|c|c|c|c|c|c|c|c|c|c|}
\hline & \multicolumn{4}{|c|}{ Gender (\%) } & \multicolumn{6}{|c|}{ Ages (\%) } \\
\hline & \multicolumn{2}{|l|}{ Male } & \multicolumn{2}{|c|}{ Female } & \multicolumn{2}{|c|}{ 19-35 Years } & \multicolumn{2}{|c|}{ 35-55 Years } & \multicolumn{2}{|c|}{ 55-70 Years } \\
\hline Parameters & Yes & No & Yes & No & Yes & No & Yes & No & Yes & No \\
\hline \multicolumn{11}{|c|}{ Cultivated Cereals } \\
\hline Sorghum & 75.3 & 24.7 & 85.7 & 14.3 & 75.6 & 24.4 & 71.4 & 28.6 & 100.0 & 0.0 \\
\hline Millet & 59.1 & 40.9 & 42.9 & 57.1 & 41.5 & 58.5 & 65.3 & 34.7 & 85.7 & 14.3 \\
\hline Maize & 98.9 & 1.1 & 100.0 & 0.0 & 100.0 & 0.0 & 98.0 & 2.0 & 99.0 & 1.0 \\
\hline Fonio & 1.1 & 98.9 & 0.0 & 100.0 & 2.4 & 97.6 & 0.0 & 100.0 & 0.0 & 100.0 \\
\hline Others & 0.0 & 100.0 & 0.0 & 100.0 & 0.0 & 100.0 & 0.0 & 100.0 & 0.0 & 100.0 \\
\hline \multicolumn{11}{|c|}{ Rain sufficiency to cereal's grow } \\
\hline & 24.7 & 75.3 & 57.1 & 42.9 & 19.5 & 80.5 & 32.7 & 67.3 & 28.6 & 71.4 \\
\hline \multicolumn{11}{|c|}{ Rain breaks during rainy seasons } \\
\hline & 98.9 & 1.1 & 100.0 & 0.0 & 100.0 & 0.0 & 98.0 & 2.0 & 100.0 & 0.0 \\
\hline \multicolumn{11}{|c|}{ Water used to compensate rain break } \\
\hline Rivers & 0.0 & 100.0 & 0.0 & 100.0 & 0.0 & 100.0 & 0.0 & 100.0 & 0.0 & 100.0 \\
\hline Wells & 2.2 & 97.8 & 0.0 & 100.0 & 0.0 & 100.0 & 4.0 & 95.9 & 2.1 & 97.9 \\
\hline Dew & 45.2 & 54.8 & 28.6 & 71.4 & 43.9 & 56.1 & 42.9 & 57.1 & 71.4 & 28.6 \\
\hline Others & 0.0 & 100.0 & 0.0 & 100.0 & 0.0 & 100.0 & 0.0 & 100.0 & 0.0 & 100.0 \\
\hline \multicolumn{11}{|c|}{ Dew is the same as rain } \\
\hline & 15.1 & 79.6 & 0.0 & 100.0 & 12.2 & 85.4 & 14.3 & 77.6 & 28.6 & 71.4 \\
\hline \multicolumn{11}{|c|}{ Period of intense dew } \\
\hline None & 0.0 & 100.0 & 0.0 & 100.0 & 0.0 & 100.0 & 0.0 & 100.0 & 0.0 & 100.0 \\
\hline Mornings & 82.8 & 17.2 & 42.9 & 57.1 & 80.5 & 19.5 & 83.7 & 16.3 & 71.4 & 28.6 \\
\hline Noons & 3.2 & 96.8 & 0.0 & 100.0 & 2.4 & 97.6 & 2.0 & 98.0 & 14.3 & 85.7 \\
\hline Nights & 41.9 & 58.1 & 100.0 & 0.0 & 36.6 & 63.4 & 46.9 & 53.1 & 71.4 & 28.6 \\
\hline \multicolumn{11}{|c|}{ Materials on which dew is observed } \\
\hline None & 0.0 & 100.0 & 0.0 & 100.0 & 0.0 & 100.0 & 0.0 & 100.0 & 0.0 & 100.0 \\
\hline Grass & 100.0 & 0.0 & 100.0 & 0.0 & 100.0 & 0.0 & 100.0 & 0.0 & 100.0 & 0.0 \\
\hline Pane & 20.4 & 79.6 & 0.0 & 100.0 & 24.4 & 75.6 & 18.4 & 81.6 & 0.0 & 100.0 \\
\hline roofs & 44.1 & 55.9 & 42.9 & 57.1 & 43.9 & 56.1 & 38.8 & 61.2 & 67.1 & 42.9 \\
\hline Naked soil & 26.9 & 73.1 & 0.0 & 100.0 & 26.8 & 73.2 & 28.6 & 71.4 & 0.0 & 100.0 \\
\hline \multicolumn{11}{|c|}{ Factors affecting dew occurence } \\
\hline Wind & 33.3 & 66.7 & 0.0 & 100.0 & 22.0 & 78.0 & 36.7 & 63.3 & 57.1 & 42.9 \\
\hline Cloud cover & 34.3 & 65.6 & 28.6 & 71.4 & 39.0 & 61.0 & 32.7 & 67.3 & 28.6 & 71.4 \\
\hline $\begin{array}{l}\text { Soil } \\
\text { temperature }\end{array}$ & 46.2 & 53.8 & \begin{tabular}{|l|}
14.3 \\
\end{tabular} & 85.7 & 39.0 & 61.0 & 46.9 & 53.1 & 42.9 & 57.1 \\
\hline Seasons & 38.7 & 61.3 & 85.7 & \begin{tabular}{|l|}
14.3 \\
\end{tabular} & 43.9 & 56.1 & 61.2 & 41.9 & 42.3 & 57.7 \\
\hline Others & 8.6 & 91.4 & \begin{tabular}{|l|}
0.0 \\
\end{tabular} & 100.0 & 12.2 & 87.8 & 4.1 & 95.9 & 14.3 & 85.7 \\
\hline \multicolumn{11}{|c|}{ Forecast dew during cereal growth } \\
\hline & 78.5 & 20.4 & 100.0 & 0.0 & 82.9 & 14.6 & 75.5 & 24.5 & 85.7 & 14.3 \\
\hline \multicolumn{11}{|c|}{ Dew helps your cereal's growth } \\
\hline & 79.6 & 19.4 & \begin{tabular}{|l|}
85.7 \\
\end{tabular} & \begin{tabular}{|l|l|}
14.3 \\
\end{tabular} & 87.8 & 9.8 & 73.5 & 26.5 & 71.4 & 28.6 \\
\hline
\end{tabular}

\section{CONCLUding Remarks}

The recognition of rain shortage constitutes a core knowledge that makes growers sow their cereals at the best moment of the rainy season to prevent unpredictable rain shortages $(99 \%$ of the respondents are victim of rain shortage). For that purpose, they rely on dew as an alternate source of water for their cereals, suggesting that dew directly influences water management for cereals growth: $99 \%$ of the respondents agree that dew water is beneficial to cereals growth. These responses suppose that the majority of farmers, in their experience for agriculture, notice the diminution of water resources and also relate meteorological parameters (wind, rain, temperature) to dew formation. The high percentage regarding the questions related to the seasons is in agreement with scientific literature data [7] concerning the region.

The definitions and justifications that growers give to illustrate how they understand the dew process contain the main scientific terms to build a real definition of what is dew. They mention words like "high air humidity", "night time", "and early morning", "clear sky, leaves", “plants "," dew substrates and air temperature". Even if they do not mention the dew point temperature (the temperature at 
which water vapor reaches $100 \%$ relative humidity and can condense into liquid), the terms that they use, in trying to give dew definition, are mainly used to build an exact scientific definition of dew. Growers also differentiate dew from fog, using the same wording as in literature [8]. But they mistake dewfall as rain droplets falling from the sky. This is presumably because they usually observe abundant dew in September (83\%), a transition month between the end of rainy season and the beginning of dry season. Confusion could be made between rain droplets and dew drops condensed on plant's leaves, on which $100 \%$ declare to often observe dew. Also the confusion could be explained by their low academic instruction level, which may make them misunderstand the questions to indicate exactly the difference between rain and dew. Nevertheless, respondents affirm that dew is not fog, as declared by $81 \%$ of them regardless of their gender or ages (Table 3 ). But when one considers the responses they give in view of the sown cereals, the growers responses depend mainly on maize (99\%) and sorghum (58\%) sowers. The answers indicate that $100 \%$ of the farmers sowing both maize and sorghum know dew and fog, which are two different phenomena. On the other hand, they think that dew can be used for irrigation. In addition, farmers indicate that cloud cover and high wind speed inhibit dew formation, as noted in literature $[2,9]$. They also report that the period from August to October is beneficial to dew formation. Meteorological observations in Guéné [7] show that this period coincides with the transition period from rainy to dry season. Hence, the crops that are delayed because of lack of rain can benefit from dew season to finish their growth cycle and ripen.

Based on their experience, most of the growers thus confirm that dew contributes in cereal growth, particularly in flowering and maturation stage (52\% and 64\%, respectively), where a lack of water is critical for fruit formation. While they do not precisely know the process by which dew forms from humid air and is utilized by plants, farmers utilize dew for cereals by enhancing it accumulation around plant's roots. The majority of farmers declare to forecast $(80 \%)$ and integrate dew periods in their annual agricultural activities. Growers think that dew and humidity around cereals allow their leaves to be green thanks to the contribution of dew to plant photosynthetic activities. Dew is said to be a major factor affecting water use efficiency in the water-stressed regime, in agreement with literature [9]. Growers also claim that dew is an important source of moisture in the air in semi-arid areas (like Guéné) and creates the best conditions for plants growth on early morning for two to three hours after sunrise. It is why $80 \%$ experienced farmers take account of dew before and during cereals growth. This practical knowledge of dew formation and dew effects on plants is important for agriculture in general and for cereals in particular at Guéné. On the other hand, some growers also indicate that dew can be harmful for plants and cereals seedling, in accordance with literature $[2,4]$. Growers highlight the interest of having a technology for dew collection but are uncertain about the water amount that could be collected.

Eventually, the study concludes that farmers' perceptions of dew mirror the scientific literature, though their perceptions are based on practical experience. The grower's opinion indeed reflects their life and agricultural work conditions, characterized by a keen knowledge of meteorological environment and poverty of means and life conditions. One notes that the responses to the main questions are not related to gender and ages as shown in Table 3. All the farmers respond to the different questions in the same way, however the responds vary dependently from the sown cereals.

\section{ACKNOWLEDGMENT}

We thank the International Foundation for Science (IFS) and the International Development Research Center (IDRC) and Stockholm Environment Institute (SEI) for their research grant support.

\section{REFERENCES}

[1] Field, C;B;, Barros, V., Stocker, T.F., Qin, D., Dokken, D.J., Ebi, K.L., Mastrandrea, M.D., Mach, K.J, Plattner, G.K., Allen, S.K., Tignor, M., Midgley, P.M., (eds.), 2012. Managing the Risks of Extreme Events and Disasters to Advance Climate Change Adaptation. A Special Report of Working Groups I and II of the Intergovernmental Panel on Climate Change (IPCC), 2012. Cambridge University Press, Cambridge, UK, and New York, NY, USA.

[2] Beysens, D., 2018. Dew Water. River Publisher, Aalborg, Denmark.

[3] Tomaszkiewicz, M., AbouNajm, M., Beysens, D., Alameddine, I., BouZeid, E, El-Fadel, M., 2015. Dew as a sustainable non-conventional water resource: a critical review. Environmental Reviews, 23, 425-442.

[4] Fang, J., 2013. A review on eco-hydrological effects of condensation water. Sciences in Cold and Arid Regions. 5, 0275-0281. 
[5] Awanou, C.N., Hazoumé, R.P., 1997. Study of natural condensation of atmospheric humidity. Renewable Energy 10, 19-34.

[6] Koto n'Gobi, G., Beysens, D., 2014. Faire de l'eau à partir de l'air. In Brèves de Maths, Mathématique de la planète terre. Andler A, Bel L, Benzoni S, Goudon T, Imbert C, Rousseau, A. (eds.), 2014. Nouveau Monde Éditions, Paris, France. p. 212.

[7] Lélé, M.I., Lamb, P.J., 2010. Variability of Intertropical Front (ITF) and rainfall over West African soudano-sahel. J. Clim. 23, 3984-4004.

[8] Shemenauer, R.S., 1994. Fog collection's role in water planning for developing countries. United Nations Journal of natural resources forum 18, 91-100.

[9] Ben-Asher, J., Alpert, P., Ben-Zvi, A., 2010. Dew is a major factor affecting vegetation water use efficiency rather than a source of water in the eastern Mediterranean area. Water Resources Research 46, W10532.

\section{AUTHOR'S BIOGRAPHY}

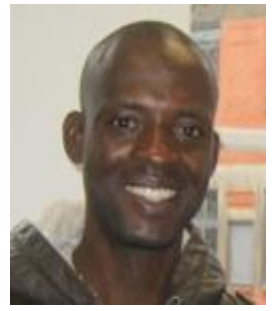

Gabin Koto N'gobi, PhD in Applied Physics (2014), Master of Science in Hydrology and Water Resources Management, is lecturer of Physics at AbomeyCalavi University (Benin, West Africa) since 2015. He is associate researcher in "Laboratoire de Physique du Rayonnement (LPR) at Abomey-Calavi University" and represents the OPUR International Organization for Dew Utilization in Benin. $\mathrm{He}$ is currently the deputy Coordinator of Renewable Energy bachelor school at Abomey-Calavi University. His studies are oriented toward the research of strategies for climate mitigation on human beings in arid and semi-arid areas. His studies since 2009 focus on how dew water can be helpful to agriculture in arid lands. He is author and co-author of seven papers related to the above topic and hydrology.

Basile Kounouhéwa, PhD in Physics (1999), is senior professor of Physics and lecturer at AbomeyCalavi University (Benin, West Africa). He is the Director of "Laboratoire de Physique du Rayonnement (LPR) at Abomey-Calavi University" where he carries out with his team researches oriented toward Renewable Energy and Atmospheric Physic. Professor Kounouhéwa is also the Head of Renewable Energy bachelor school at Abomey-Calavi University. His studies are concerned with Energy exchange between atmosphere and land grasses, Energy efficiency and maritime energy. He is author and co-author of more than 100 papers related to Energy and applied physics.

Clément A. Kouchadé, PhD in Physics, is senior professor of Physics and lecturer at Abomey-Calavi University (Benin, West Africa), also emeritus Director of Benin National Wood Office. He is the deputy Director of'Laboratoire de Physique du Rayonnement (LPR) at Abomey-Calavi University" where he carries out researches oriented toward Renewable Energy and Wood Sciences. Mr Kouchadé is also the Coordinator of Renewable Energy bachelor school at Abomey-Calavi University. His studies concerned the valorization of local Wood. He is author and co-author of more than 50 papers related to Energy and applied physics.

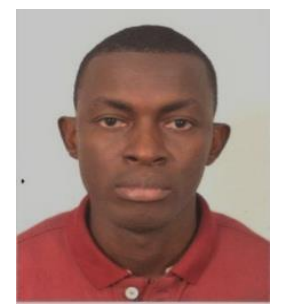

Romuald Anago is a Research Coordinator at Innovations for Poverty Action (IPA) Francophone West Africa. He oversees Research Associates' work, which includes ensuring that IPA requirements for data quality assurance is followed, deliverables timelines on projects are respected, and provides technical assistance and capacity building support to research staff. Prior to join IPA, he worked as a Research Associate and Interim Director at Institute for Empirical Research Political Economy (IERPE). He has also worked as a statistician, data manager, and consultant for many institutions. RomualdAnago has a M.A. in Public Economics and Applied Statistics from IERPE and a Master's Degree in Mathematics from the University of Abomey-Calavi in Benin. Romuald was previously (2016-2017) based at IPA's office in Mali, where he mainly worked on the follow-ups of two projects on Agricultural Microfinance and Speed School for out-ofschool children.

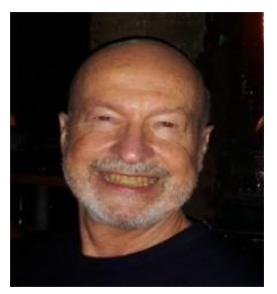

Daniel Beysens, $\mathbf{P h D}$ in Physics and in Engineering is a world specialist of water collection from air. He is the co-founder and President of OPUR International Organization for Dew Utilization. He is also emeritus Director of Research at Ecole Supérieure de Physique et Chimie Paris, where he carries out with his team experimental and theoretical study on dew condensation and phase transition. $\mathrm{He}$ started the field at the Alternative Energies and Atomic Energy Commission 
(CEA) when he was Head of Institute. He has authored or co-authored more than 450 publications in international scientific Journals and 12 books. He was awarded many prices in Physics and Environmental Sciences and is Knight of the Order of Academic Palms.

Citation: Gabin Koto N'Gobi et.al. “Perception of Dew by Cereal Growers in Semi-Arid Climate (Guéné, North Benin)" International Journal of Humanities Social Sciences and Education (IJHSSE), vol 5, no. 9, 2018, pp. 25-36.. doi: http://dx.doi.org/10. 20 431/2349-0381.0509005.

Copyright: (c) 2018 Authors. This is an open-access article distributed under the terms of the Creative Commons Attribution License, which permits unrestricted use, distribution, and reproduction in any medium, provided the original author and source are credited. 